\title{
ANALISIS PENGARUH MAKROEKONOMI, KOMODITAS DUNIA, DAN INDEKS DUNIA TERHADAP INDEKS HARGA SAHAM GABUNGAN (IHSG) PADA PERIODE 2014-2019
}

\author{
Fadhil Ahmad \\ Universitas Negeri Surabaya \\ fadhilahmad16080574051@mhs.unesa.ac.id
}

Abstract

This research explains the influence of inflation, Exchange Rate, BI Rate, GDP, World Gold Price, Crude Oil Price, Dow Jones Industrial Average (DJIA), and Nikkei 225 toward Jakarta Composite Index (JCI). Type of research used in causality research with a quantitative approach. The sample was based on daily time series data from 1 January 2014 until 31 December 2019, using a complete sampling method that consists of 2190 samples. This research used a generalized autoregressive conditional heteroskedasticity (GARCH) method. The result of hypothesis testing by the GARCH method shows that the World Gold Price and Dow Jones Industrial Average significant have a positive effect, Then the Nikkei 225 significant have a negative effect, and then the Inflation, Exchange Rate, BI Rate, and GDP have not significant to the Jakarta Composite Index (JCI). The implication of this research provides information to investors who must pay attention to World Gold Price, Dow Jones Industrial Average, and Nikkei225 if they want to invest in Indonesian.

Keywords: Jakarta Composite Index (JCI); macroeconomic; world comodites; world index

\section{PENDAHULUAN}

Investasi telah mengalami peningkatan yang cukup tinggi. Pada tahun 2014, data Badan Koordinasi Penanaman Modal (BKPM) mencatatkan investasi Penanaman Modal Asing (PMA) sebesar Rp307 triliun dan PMDN sebesar Rp156,1 triliun sehingga total nilainya mencapai Rp463,1 triliun. Berlanjut ke tahun 2018, realisasi investasi mencapai Rp721,3 triliun dengan kenaikan mencapai $64 \%$ dari tahun 2014 (BKPM, 2019). Tidak hanya dana dan investor yang terlibat, tetapi dengan adanya bermacam-macam instrumen investasi yang dapat dijadikan opsi lain dari investasi. Tingginya perkembangan tersebut, akan menyumbangkan persediaan sumber daya manusia yang berupaya memengaruhi pengelolaan investasi secara baik. Oleh karena itu, mengetahui manajemen investasi benar-benar amatlah bermanfaat dalam menanggapi tuntutan tersebut. Di samping itu, apresiasi tentang apa itu pasar financial seperti pasar uang dan di pasar modal, variation of instruments yang dipasarkan pada pasar modal, serta metode trading yang terjadi di pasar modal amatlah krusial untuk menyampaikan potret tentang bermacam opsi dari investasi yang ada bagi investor (Tandelilin, 2010:1).

Menurut Diskartes (2017) terdapat beberapa instrumen dalam sarana berinvestasi, salah satunya ialah pasar modal. Salah satu instrument yang paling diminati oleh investor adalah saham. Berinvestasi di saham terdapat risiko yang besar dengan potensi profitabilitas yang lebih tinggi daripada dengan variasi investasi yang lainnya. Melakukan investasi pada pasar modal, investasi saham memerlukan pengatahuan yang cukup dan pengalaman yang baik untuk menganalisis dan membedakan saham mana yang dapat dibeli, dijual dan layak dimiliki oleh investor. Capital Market mempunyai peran sangat yang penting untuk sektor swasta, sektor pemerintah dan pada seluruh kalangan masyarakat. Sektor swasta dapat menjadikan pasar modal sebagai alternatif untuk pembiayaan usaha melalui penerbitan efek, sedangkan bagi sektor pemerintah pasar modal ialah sarana penggerak dalam pembangunan perekonomian. Hal tersebut dirasa cukup penting, karena mengingat keterbatasan pemerintah dalam menyediakan dana untuk pembangunan yang sangat terbatas (Gunawan, 2014).

Data Asean Exchange (2019), Indeks harga saham di Asean meliputi Jakarta Composite Index, Hanoi Stock Exchange, Kuala Lumpur Stock Exchange Malaysia, Philippine Stock Exchange Index, The Stock Exchange of Thailand, dan Strait Time Singapore Stock Exchange terintegrasi dalam Asean 
Fadhil Ahmad. Analisis Pengaruh Makroekonomi, Komoditas Dunia, dan Indeks Dunia terhadap Indeks Harga Saham Gabungan (IHSG) pada Periode 2014-2019

Exchanges. Asean Exchanges adalah gabungan dari keenam stock market dari negara-negara di $A S E A N$, dengan harapan lebih banyak menumbuhkan potensi investasi kepada negara-negara di kawasan tersebut (Pamungkas, 2018). Tujuan dibentuknya ASEAN Exchanges untuk mempromosikan pertumbuhan pasar modal ASEAN dengan merampingkan akses ke ASEAN, memperkenalkan harmonisasi lintas batas dan menciptakan produk-produk sentris ASEAN. Gabungan stock market di kawasan ASEAN, dengan begitu dapat diharapkan membawa manfaat kepada negara-negara yang tergabung di dalamnya (Puspitasari et al, 2015).

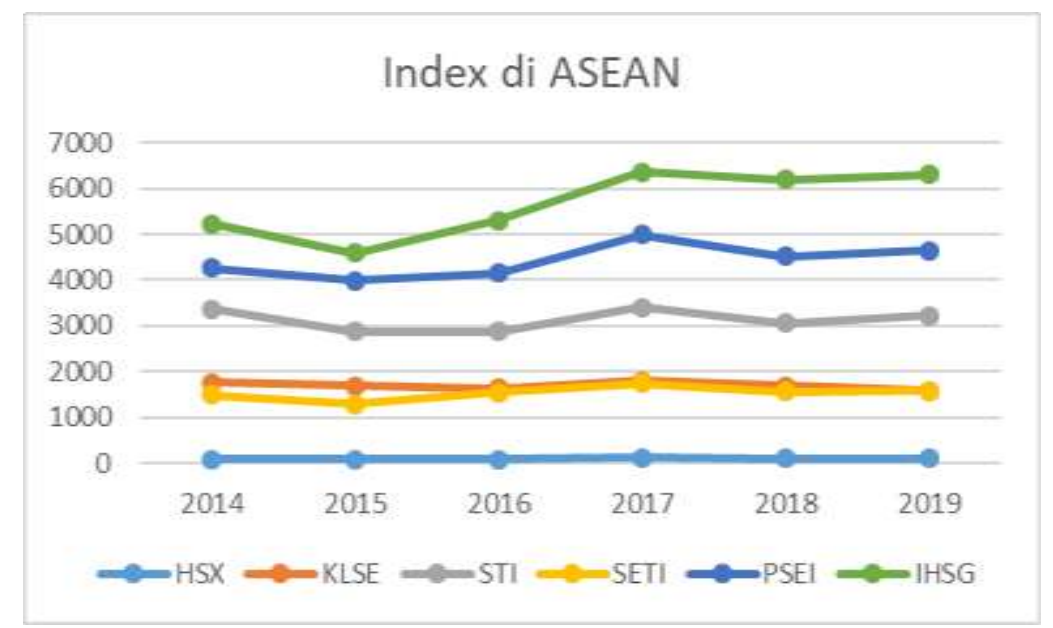

Sumber : id.investing.com (data diolah)

\section{Gambar 1. GRAFIK INDEKS BURSA ASEAN PERIODE 2014-2019}

Dari gambar 1. Indeks bursa di ASEAN mengalami fluktuasi pada kurun waktu Januari 2014 s.d. Desember 2019. Data yang dimuat adalah dari closing price (penutupan harga). Pada tahun 2014 sampai tahun 2015, hampir semua bursa di ASEAN mengalami penurunan dan pada tahun 2016 sampai tahun 2017, bursa di ASEAN cenderung mengalami kenaikan. Namun, IHSG mempunyai nilai yang tertinggi dari tahun 2014-2019 dari harga indeks yang lainnya yang ada di ASEAN yaitu sebesar 6.299 pada Desember 2019. Tertinggi setelah IHSG adalah PSEI yaitu Philippine Stock Exchange Index yang mempunyai nilai pada tahun 2019 yaitu sebesar 4649. Hanoi index mempunyai nilai paling rendah yaitu 102 pada tahun 2019.

Menurut Tandelilin (2010:341) perubahan yang terjadi pada faktor makro ekonomi dapat memberikan pengaruh pada pasar modal yang menyebabkan faktor makro ekonomi memiliki potensi untuk membentuk harga saham. Terjadinya fluktuasi pada pasar modal berhubungan dengan varabel makroekonomi yang menyebabkan terjadinya perubahan. Terdapat beberapa perubahan faktor makroekonomi yakni inflasi, kurs, suku bunga dan PDB yang berhubungan dengan pasar modal dan menyebabkan faktor makroekonomi memengaruhi terbentuknya harga saham (Zabidi \& Asandimitra, 2018). Pada masa depan, makroekonomi akan berpengaruh dalam hal untuk memutuskan dalam berinvestasi yang dapat memberikan keuntungan. Investor perlu memikirkan berbagai macam indikator makroekonomi yang akan berguna dalam pembuatan keputusan investasi (Gunawan, 2014).

Selain faktor makroekonomi yang memengaruhi harga saham, faktor eksternal juga dapat memengaruhi pasar modal seperti pada komoditas dan indeks dunia, di antaranya pada komoditas dunia seperti harga minyak dunia, harga emas dunia. World Oil Price mengakibatkan pada sektor minning terjadi peningkatkan keuntungan emiten, meningkatnya laba emiten memberi sinyal positif yang akan menyebabkan stock price naik dan stock market akan naik nilainya (Rustyaningsih, 2018). Pada umumnya harga emas di dunia memiliki hubungan terbalik terkait situasi perekonomian dan berkarakter cyclical, yang menandakan bahwa pada saat perekonomian dan pasar sedang meningkat, world gold price mengarah pada fluktuasi yang stabil. Namun sebaliknya, emas akan diincar tatkala terjadinya ketidakpastian yang tinggi atau mengalami fluktuasi yang tinggi di pasar akan menyebabkan harga emas meningkat pesat. Stock price yang beranjak mengikuti situasi pasar dan perekonomian ketika kondisi baik akan naik dan ketika kondisi tidak pasti akan turun (Frensidy, 
2013:38). Biasanya pasar mempunyai dampak yang berpengaruh terhadap kinerja pasar saham di Indonesia adalah yang tergolong maju seperti Dow Jones Industrial Average pada bursa Amerika, Nikkei225 pada bursa Jepang, dan sebagainya (Pribadi, 2017).

Beberapa penelitian sebelumnya menunjukkan terjadinya gap pada variabel-variabel penelitian yang akan diteliti. Seperti pada beberapa riset dari Nasser et al (2017), Novianto (2010), Zoa et al (2014), dan Handiani (2014) menyatakan bahwa terdapat pengaruh pada variabel inflasi, kurs, bi rate, pdb terhadap pasar saham. Pada beberapa penelitian dari Andiyasa et al (2014), Marjohan (2015), Kowanda et al (2014) membuktikan bahwa ada pengaruh pada variabel Harga Emas Dunia, Harga Minyak Dunia, DJIA, Nikkei225 terhadap pasar saham. Beberapa penelitian dari Rustyaningsih (2018), Pardede et al (2016), Tjandrasa \& Sutjiati (2016), dan Nordin et al (2014) membuktikan bahwa tidak terdapat pengaruh pada variabel Inflasi, Kurs, Bi Rate, PDB, Harga Emas Dunia, Harga Minyak Dunia, DJIA Dan Nikkei225 terhadap Indeks Harga Saham Gabungan. Berdasarkan research gap yang telah ditemukan, penelitian ini bertujuan untuk mengetahui dampak dari perubahan makroekonomi, komoditas dunia dan indeks dunia terhadap pasar saham.

\section{KAJIAN PUSTAKA DAN PENGEMBANGAN HIPOTESIS}

\section{Signalling Theory}

Signalling Theory yaitu konsep yang mempelajari tentang fluktuasi harga di pasar yang akan memberikan dampak kepada pengambilan keputusan dalam berinvestasi (Fahmi, 2012:100). Bagi investor, fluktuasi stock price di stock market akan memberikan informasi sinyal berupa sinyal baik maupun sinyal buruk. Apapun berita yang telah terbentuk akan membuat pengaruh pada situasi stock value pada emiten yang menyebabkan memengaruhi pengambilan keputusan pada investor yang menjadi kelompok yang menangkap signal tersebut (Tandelilin, 2010:579). Pada teori sinyal, terdapat konsekuensi logis dari teori sinyal, bahwa ada insentif bagi semua manajer yang memberikan sinyal mengenai keuntungan yang diperoleh di masa depan karena jika investor mempercayai sinyal tersebut, maka stock price akan naik dan pemilik saham akan memperoleh profit. Apabila adanya berita tersebut ditangkap menjadi sinyal yang bagus menurut investor, maka akan menyebabkan dampak dalam volume trading saham (Godfrey, 2010:375).

\section{Contagion Effect Theory}

Menurut Zabidi \& Asandimitra, (2018), Contagion effect theory adalah sebuah pengaruh yang disebabkan beberapa situasi ekonomi pada kawasan tertentu terhadap situasi ekonomi terhadap negara yang mempunyai keterkaitan pada kawasan tersebut. Peristiwa dampak ekonomi yang terjadi pada suatu kawasan biasanya akan memberikan pengaruh kejadian ekonomi pada negara/kawasan lainnya di dunia. Dampaknya memiliki kecondongan hampir sama ataupun tidak akan sama dampaknya pada kawasan yang terkena dampak terhadap negara lainnya, tergantung terjalinnya ikatan dan kerja sama pada bidang ekonomi pada negara tersebut (Maulinda, 2018).

Contagion effect akan berdampak melalui penggabungan faktor finance mampu menyebabkan efek spillover pada negara-negara tertentu diakibatkan oleh perubahan pada makroekonomi pada suatu negara. Pengaruh faktor keuangan dapat membuat variasi dalam berproduksi menggunakan re-alokasi modal, tetap dengan daya komparatif pada negara-negara tersebut (Robiyanto \& Fajar Hartanto, 2018).

\section{ARCH/GARCH}

Pengertian dari ARCH/GARCH merupakan suatu rancangan perihal fungsi autoregressive bahwa variansi yang di asumsikan beralih terhadap waktu dan nilai variansi ini disebabkan oleh beberapa data sebelumnya (Juliana et al, 2019:15). Teknik ARCH/GARCH digunakan terutama untuk menjawab permasalahan terjadinya volatilitas pada data ekonomi dan bisnis, terlebih dalam bidang keuangan. Dalam hal ini berdampak pada model metode forecasting sebelumnya masih kurang mendekati kondisi aslinya (Pamungkas \& Prasetiono, 2018). Metode GARCH dapat digunakan untuk 
Fadhil Ahmad. Analisis Pengaruh Makroekonomi, Komoditas Dunia, dan Indeks Dunia terhadap Indeks Harga Saham Gabungan (IHSG) pada Periode 2014-2019

pemodelan pada data yang bersifat heteroskedastisitas tanpa menghilangkan sifat heteroskedastisitas tersebut. Bentuk umum dari model GARCH dengan ordo m,s (1).

$\sigma_{t}^{2}=\alpha_{0}+\sum_{i=1}^{m} \alpha_{i} a_{t-1}^{2}+\sum_{j=i}^{s} \beta_{j} \sigma_{t-j}^{2}$

Keterangan:

$\sigma_{t}^{2} \quad=$ Varian data ke-t

$\alpha_{0} \quad=$ Konstanta

$\alpha_{i} \quad=$ Parameter ARCH

$\beta_{j} \quad=$ Parameter GARCH

$a_{t-i}^{2} \quad=$ Residual ke $\mathrm{t}-\mathrm{i}$

\section{Indeks Harga Saham Gabungan (IHSG)}

IHSG berperan layaknya indikator pada pasar modal, yang berarti fluktuasi indeks mencerminkan situasi market pada saat tertentu, apakah market dalam keadaan kuat atau lemah. Dengan diketahuinya indeks saham, akan mampu memahami fluktuasi stock market price pada saat tersebut, dengan adanya fluktuasi harga dapat dianalisis kondisi pasar apakah sedang mengalami tren bearish, bullish atau sideway (Maulinda, 2018). Data IHSG pada riset ini diambil dari closing price IHSG time period harian selama periode penelitian.

\section{Inflasi}

Inflasi menurut Astiyah \& Suseno (2009:2) adalah sebagai naiknya peredaran uang atau meningkatknya likuiditas perekonomian pada suatu negara. Pemahaman itu berpatokan terhadap kejadian yang disebabkan oleh terjadinya peningkatan peredaran uang yang akan menimbulkan dampak dengan melambungnya harga-harga pada komoditas tertentu. Seiring pesatnya perkembangan, inflasi juga bisa disebut sebagai tendensi terjadi peningkatan nilai-nilai atas barang dan jasa yang terus-menerus mengalami kenaikan. Data Inflasi pada penelitian ini menggunakan Indeks Harga Konsumen (IHK) periode per satu bulan selama januari 2014 - desember 2019. Menurut Rustyaningsih (2018), inflasi dapat dihitung dengan rumus (2).

Inflasi $=\frac{I H K t-I H K t-1}{I H K t-1}$

Keterangan:

IHK $_{\mathrm{t}} \quad$ : IHK Periode $_{\mathrm{t}}$

IHK $_{\mathrm{t}-1} \quad$ : IHK Periode $\mathrm{t}-1$

Kurs

Setiap kegiatan transaksi di level internasional selalu menggunakan valuta asing (valas). Terdapat kepentingan untuk menukarkan mata uang negara tertentu menjadi mata uang negara lainnya. Peristiwa tersebut dapat mengakibatkan terbentuknya permintaan pada transaksi valuta asing. Pasar valutas asing menawarkan beberapa teknik yang bisa merampungkan transaksi yang kompleks dan bermacam-macam secara efisien dan segera. Dalam pasar valuta asing menurut Syaifuddin dkk (2015:45) Pertama adalah pasar konsumen, di mana setiap perseorangan atau perusahaan dapat melakukan transaksi valuta asing kepada perusahaan yang dapat melakukan transaksi valas ataupun pada bank. Data kurs pada riset ini adalah menggunakan nilai tengah kurs US Dollar terhadap Rupiah Indonesia dollar dalam satu bulan selama Januari 2014-Desember 2019. Menurut Mangala \& Rani (2015) kurs dapat dihitung dengan rumus (3).

Kurs Rupiah $=\frac{\text { KursTengaht-KursTengah t-1 }}{\text { Kurs Tengaht-1 }}$

Keterangan:

Kurs Tengah $_{\mathrm{t}} \quad$ : Kurs Tengah Periode ${ }_{\mathrm{t}}$

Kurs Tengah $_{\mathrm{t}-1}$ : Kurs Tengah Periode $\mathrm{t}_{\mathrm{t}-1}$ 


\section{BI Rate}

Menurut Pohan dalam Alim (2014) Perubahan tingkat bunga yang tidak sesuai secara langsung dapat menyebabkan gangguan perkembangan perbankan. Level suku bunga yang tinggi akan menaikkan minat investor untuk menabung pada instrument deposito sehingga jumlah dana yang masuk perbankan akan bertambah. Jika tingkat suku bunga cenderung tinggi berdampak pada peningkatan output cost yang harus ditanggung oleh para pengusaha sehingga menyebabkan anjloknya proses produksi pada negara tersebut. Data Suku Bunga yang akan dipakai untuk penelitian ini adalah BI Rate dengan data bulanan yang telah ditetapkan oleh Bank Indonesia selama periode penelitian.

\section{Produk Domestik Bruto (PDB)}

Produk Domestik Bruto yaitu perhitungan market value pada goods and services yang telah dihasilkan oleh negara tertentu yang diperoleh dengan faktor produksi pada masyarakat yang memiliki usaha yang selalu di update pada periode triwulan (Sukirno, 2011:34). Kondisi perekonomian suatu negara dapat diperkirakan dengan menghitung tingkat pendapatan masyarakat yang dihasilkan pada negara tersebut. Menghitung PDB dengan menghitung jumlah pemasukan semua masyarakat dalam perekonomian pada suatu negara dan jumlah pembelanjaan negara untuk membeli barang atau jasa hasil dari perekonomian (Otorima \& Kesuma, 2016). Data PDB yang digunakan yaitu PDB sektor riil lapangan usaha pada setiap triwulanan selama pada periode penelitian.

\section{World Gold Price}

Emas adalah suatu benda yang sangat berharga dan paling diminati masyarakat setelah forex. Negara dengan sebutan G-7 adalah ke tujuh negara yang mempunyai perekonomian terbesar di dunia yaitu Jerman, Amerika, Italia, Jepang, Kanada, Inggris, dan Perancis, nilai mata uang negara tersebut akan diikuti dengan kenaikan atau penurunan harga emas dunia (Dwiati \& Ambarwati, 2016). Apabila terjadi peningkatan nilai mata uang pada negara tersebut, maka akan semakin tinggi juga harga emas di dunia (Handiani, 2014). Data Harga Emas Dunia yang diambil adalah data closing price harian selama periode penelitian.

\section{World Oil Price}

World oil price merupakan commodity yang paling diminati untuk membuat suatu negara semakin bertumbuh. Crude oil yang akan diproduksi menjadi pangkal energi yang akan menjadi Liquified Petroleum Gas (LPG) yang biasanya untuk kebutuhan memasak, pelumas, solar, minyak tanah, bensin dan lain-lain (Pardede et al, 2016). Minyak dunia yang di perjual belikan pada West Texas Intermediate (WTI) adalah crude oil yang memiliki kualitas sangat baik. Jenis minyak ini pada umumnya dijadikan untuk bahan bakar kendaraan di seluruh dunia, ini yang mengakibatkan crude oil price dibuat parameter pada perdagangan minyak mentah di seluruh dunia (Pribadi, 2016). Data Harga Minyak Dunia yang diambil merupakan data closing price harian selama periode penelitian.

\section{Dow Jones Industrial Average (DJIA)}

Menurut Martin (2014) Indeks Dow Jones 30 adalah stock index paling tua di dunia dan kerap kali dipakai sebagai acuan pergerakan indeks perdagangan saham di dunia. Awalnya dirintis oleh dua orang editor Wall Street Journal dan pembuat perusahaan terkemuka Dow Jones \& Company, Charles Dow dan Edward Jones. Indeks ini lazim disebut Dow Jones Industrial Average (DJIA), dan kadangkadang dikenal juga sebagai US-30. Data DJIA yang diambil adalah data closing price harian selama periode penelitian.

\section{Nikkei225}

Menurut UFX (2016), Nikkei225 terinspirasi dari surat kabar Nikkei yang mulai menghitung indeks dari tahun 1950. Indeks Nikkei terdiri dari beberapa perusahaan yaitu terdapat 225 perusahaan di Jepang dari berbagai industri. Terdapat berbagai macam perusahaan terkemuka yang berasal dari Jepang di antaranya Kikkoman, Panasonic, Toyota, Bridgestone. Nikkei 225 merupakan indeks yang banyak dikutip oleh beberapa penelitian yang berasal dari bursa saham Tokyo yang setara juga dengan Dow Jones Industrial Average di Amerika Serikat. Data Nikkei 225 yang diambil merupakan data closing price harian selama periode penelitian. 
Fadhil Ahmad. Analisis Pengaruh Makroekonomi, Komoditas Dunia, dan Indeks Dunia terhadap Indeks Harga Saham Gabungan (IHSG) pada Periode 2014-2019

\section{Hubungan antar Variabel}

Pengaruh yang diakibatkan oleh inflasi yaitu menyebabkan kenaikan harga kebutuhan pokok sehingga masyarakat menyebabkan tertekannya keinginan untuk mengkonsumsi barang dan jasa. Pemasukan Emiten juga terjadi penurunan dan keuntungan yang diperoleh emiten akan menurun sehingga menyebabkan jumlah minat investor akan berkurang untuk menanamkan modalnya di pasar modal (Nellawati \& Isbanah, 2019). Hasil riset yang diteliti oleh Maulinda \& Purwohandoko (2018) dan (Nasser et al., 2017) mengatakan bahwasanya inflasi berpengaruh negatif terhadap pasar saham. Sebaliknya, penelitian dari (Akbar, 2016) menyatakan bahwa inflasi terdapat pengaruh positif terhadap Indeks saham.

H1: Inflasi berpengaruh terhadap Indeks Harga Saham Gabungan (IHSG) pada periode 2014-2019.

Apabila kurs Rupiah melemah dan bahan baku industri masih impor, maka akan terjadi kenaikan biaya bahan baku. Apabila terjadi kenaikan biaya bahan baku, maka profitability dari emiten akan turun sehingga daya tarik investor untuk menanamkan modalnya di pasar modal akan turun. Hal ini mengakibatkan nilai pada pasar saham akan turun (Syarif \& Asandimitra, 2015). Dalam penelitian dari Nordin et al (2014) dan Zoa et al (2014) mengatakan bahwasanya kurs berpengaruh positif dan signifikan terhadap Indeks harga saham. Sebaliknya, penelitian dari Mangala \& Rani (2015) dan Gunawan (2014) menyatakan bahwa kurs berpengaruh negatif dan signifikan terhadap Indeks harga saham.

H2: Kurs berpengaruh terhadap Indeks Harga Saham Gabungan (IHSG) pada periode 2014-2019 BI rate merupakan benchmark interst rate dalam pasar uang di Indonesia.

Tingkat bunga akan berbeda dalam periode waktu berjalan dan diputuskan oleh bank sentral suatu negara, atau di Indonesia disebut Bank Indonesia (BI). Ketika suku bunga dinaikkan, jumlah perusahaan yang meminjam uang dari bank berkurang. Oleh karena itu, perusahaan perlu mengurangi pengeluarannya sehingga jumlah arus kas masa yang akan turun. Hasilnya, akan menurunkan harga saham di suatu perusahaan. Jika cukup banyak perusahaan menurunkan harga saham mereka, maka itu akan memengaruhi pasar saham utama secara keseluruhan (Nasser et al, 2017). Hasil riset yang diteliti oleh Pamungkas \& Prasetiono (2018) dan Nordin et al (2014) mengatakan bahwasanya $B I$ rate berpengaruh positif dan signifikan terhadap Indeks harga saham. Sebaliknya, Penelitian dari Nasser et al (2017) dan Zoa et al (2014) mengatakan bahwasanya BI rate berpengaruh negatif dan signifikan terhadap Indeks harga saham.

H3: BI Rate berpengaruh terhadap Indeks Harga Saham Gabungan (IHSG) pada periode 2014-2019.

PDB adalah Produk Domestik Bruto yang menggambarkan bahwa negara tersebut telah bertumbuh atau tidak. Apabila PDB mengalami peningkatan, yang berarti pertumbuhan ekonomi pada masyarakat meningkat karena masyarakat bersifat konsumtif. Ketika masyarakat bersifat konsumtif, maka penjualan pada perusahaan akan meningkat yang tentunya juga laba dari perusahaan itu meningkat. Investor cenderung tertarik karena perusahaan mendapatkan banyak laba, pada saat pembagian deviden pasti akan lebih banyak dari biasanya. Hal tersebut mengakibatkan indeks harga saham meningkat karena ketertarikan investor (Rustyaningsih, 2018). Hasil riset yang diteliti oleh Gunawan (2014) mengatakan bahwasanya PDB berpengaruh positif dan signifikan terhadap Indeks harga saham. Sebaliknya, penelitian dari Katircioglu et al (2015) dan Nasser et al (2017) mengatakan bahwasanya PDB berpengaruh negatif terhadap Indeks harga saham.

H4: PDB berpengaruh terhadap Indeks Harga Saham Gabungan (IHSG) pada periode 2014-2019.

World Gold Price dapat memengaruhi pasar saham. Tertariknya investor pada meningkatnya harga emas adalah untuk mengambil keputusan berinvestasi pada emas daripada berinvestasi pada stock market karena berinvestasi emas memiliki risiko yang paling minim, emas menawarkan imbal hasil yang sudah pasti, karena harga emas dipastikan tidak bakal turun yang terlalu signifikan. Akibat hal tersebut memberikan efek pada stock market di suatu negara yang akan mengalami penurunan 
(Nellawati \& Isbanah, 2019). Hasil riset yang diteliti oleh (Rustyaningsih, 2018) dan (Handiani, 2014) mengatakan bahwasanya emas dunia berpengaruh positif dan signifikan terhadap Indeks harga saham. Sebaliknya, penelitian dari (Dwiati \& Ambarwati, 2016) dan (Andiyasa et al., 2014) menyatakan bahwa World Gold Price berpengaruh negatif dan signifikan terhadap indeks harga saham.

H5: Harga Emas Dunia berpengaruh terhadap Indeks Harga Saham Gabungan (IHSG) pada periode 2014-2019.

Tujuan dari crude oil diproduksi adalah untuk memenuhi kebutuhan mobilitas pada suatu negara. Crude oil adalah sumber energi utama dalam prosedur pembuatan bahan menjadi bahan jadi yang mampu memengaruhi fluktuasi stock price selain harga minyak untuk memengaruhi biaya produksi. World Oil Price sebagai comodity investasi bisa memengaruhi keputusan investor dalam berinvestasi pada stock market (Kowanda et al, 2014). Hasil riset yang diteliti oleh(Pardede et al., 2016) dan (Riga et al, 2016) mengatakan bahwasanya Minyak dunia berpengaruh positif dan signifikan terhadap Indeks Harga Saham. Sebaliknnya, penelitian dari (Andiyasa et al., 2014) dan (Kowanda et al., 2014) menyatakan bahwa Minyak dunia berpengaruh negatif dan signifikan terhadap Indeks Harga Saham.

H6: Harga Minyak Dunia berpengaruh terhadap Indeks Harga Saham Gabungan (IHSG) pada periode 2014-2019.

Hubungan integrase ekonomi yang terjadi antara Amerika Serikat dengan Indonesia juga memberikan dampak terhadap stock market antar negara. DJIA memiliki pengaruh terhadap IHSG melalui berbagai kegiatan ekonomi yang telah terjalin. Indeks DJIA apabila mengalami kenaikan berarti menandakan bahwa kemampuan perekonomian Amerika Serikat masih dalam kondisi baik. Perekonomian Indonesia akan berdampak dengan keadaan tersebut melalui aktivitas ekspor ataupun arus modal masuk, termasuk investasi pada sektor riil maupun melalui pasar modal. Amerika menjadi tujuan ekspor terbesar kedua di Indonesia (Mursalin et al, 2017). Riset yang diteliti oleh (Marjohan, 2015) dan (Kowanda et al., 2014) mengatakan bahwanya DJIA berpengaruh positif dan signifikan terhadap indeks harga saham. Sebaliknya, penelitian dari (Mursalin et al., 2017) mengatakan bahwasanya DJIA berpengaruh negatif terhadap indeks harga saham.

H7: Dow Jones Index Average berpengaruh terhadap Indeks Harga Saham Gabungan (IHSG) pada periode 2014-2019.

Perubahan nilai indeks Nikkei 225 terhadap stock market pada negara Indonesia dilatarbelakangi karena Jepang menjadi negara tujuan ekspor terbesar dari negara Indonesia. Perubahan keadaan perekonomian Jepang terlihat pada indeks Nikkei 225 memberikan pengaruh bagi perekonomian Indonesia dari kegiatan ekspor dan aliran masuk investasi asing pada sektor riil begitu juga melalui stock market yang menyebabkan meningkatnya nilai stock price di Indonesia. Jika perekonomian Indonesia meningkat, maka trust dan hasrat investor untuk berinvestasi juga akan ikut meningkat yang membuat pasar saham di Indonesia meningkat (Nellawati \& Isbanah, 2019). Menurut riset yang diteliti oleh (Marjohan, 2015) dan (Ghiffari, Kindangen, \& Tumewu, 2017) mengatakan bahwasanya Nikkei 225 berpengaruh positif dan signifikan terhadap pasar saham di indonesia. Sebaliknya, penelitian dari (Kowanda et al., 2014) dan (Andiyasa et al., 2014) menyatakan bahwa Nikkei 225 berpengaruh negatif dan signifikan terhadap pasar saham di Indonesia.

H8: Nikkei225 berpengaruh terhadap Indeks Harga Saham Gabungan (IHSG) pada periode 20142019.

\section{METODE PENELITIAN}

Riset ini tergolong dalam riset kausalitas dikarenakan riset ini merupakan dengan menduga bukti atas terdapat atau tidaknya interaksi antara variabel independen terhadap variabel dependen (Malhotra, 2010:113). Objek penelitian yang mempunyai karakteristik tertentu yang telah ditetapkan oleh peneliti 
Fadhil Ahmad. Analisis Pengaruh Makroekonomi, Komoditas Dunia, dan Indeks Dunia terhadap Indeks Harga Saham Gabungan (IHSG) pada Periode 2014-2019

yang digunakan untuk penelitian kemudian akan ditarik kesimpulan disebut populasi (Sugiyono, 2017:80). Populasi dalam riset artikel ini yaitu closing price Indeks Harga Saham Gabungan (IHSG) harian selama tanggal 1 Januari 2014 sampai dengan 31 Desember 2019. Populasi yang memiliki karakteristik tertentu dan memiliki keunikan disebut dengan sampel (Sugiyono, 2017:81) Teknik pengambilan sampel pada riset ini menggunakan metode sampling jenuh (sensus) yang berarti semua populasi digunakan untuk riset. Sampel pada riset artikel ini yaitu closing price Indeks Harga Saham Gabungan (IHSG) harian selama tanggal 1 Januari 2014 sampai dengan 31 Desember 2019 sehingga diperoleh total data sampel sebanyak 2190 hari. Teknik analisis data yang digunakan pada riset ini adalah Generalized Autoregressive Conditional Heteroskedastisitas (GARCH) dengan menggunakan analisis software Eviews10. Teknik pengumpulan data dalam riset ini menggunakan dokumentasi dengan sumber data sekunder, di unduh dari website www.investing.com, Badan Pusat Statistik dan Bank Indonesia.

\section{HASIL DAN PEMBAHASAN}

Uji unit root atau uji stasioneritas data dilakukan untuk melihat stationary data yang digunakan. Tabel 1 menunjukkan hasil pengujian uji stationer pada tingkat 1 st Difference dengan menggunakan tipe Augmented Dickey fuller. Berdasarkan tabel 1, hasil uji stationer pada tingkat 1st Difference menunjukkan hasil probabilitas $<\alpha(0,05)$ pada semua variabel yang akan diteliti, maka mean, variance, dan covariance telah konstan atau dikatakan stationer sehingga penelitian dapat dilanjutkan ke tahap selanjutnya.

\section{Tabel 1 UJI STATIONERITAS}

\begin{tabular}{cccc}
\hline Series & Prob. & Lag & Max Lag \\
\hline D(WTI) & 0.0000 & 1 & 25 \\
D(PDB) & 0.0000 & 0 & 25 \\
D(N225) & 0.0000 & 22 & 25 \\
D(KURS) & 0.0000 & 0 & 25 \\
fD(INFLASI) & 0.0000 & 0 & 25 \\
D(IHSG) & 0.0000 & 6 & 25 \\
D(EMAS) & 0.0000 & 0 & 25 \\
D(DJIA) & 0.0000 & 7 & 25 \\
D(BI_RATE) & 0.0000 & 2 & 25 \\
\hline
\end{tabular}

Sumber: Output Eviews10 (data diolah)

Identifikasi model dapat dilihat dengan cara melihat karakteristik dari ACF dan PACF. Tabel 2 menunjukkan hasil output dari plot ACF dan PACF. Berdasarkan Tabel 2, output collerogram di atas, plot ACF dan PACF, plot yang melanggar batas (cutten-off) atau terlihat sangat menonjol adalah pada baris ke-dua belas sehingga model ARIMA yang memungkinkan untuk dibuat yaitu model ARIMA $(12,1,0)$, ARIMA $(0,1,12)$ dan ARIMA $(12,1,12)$.

Proses selanjutnya adalah pendugaan parameter model ARIMA yang terbaik. Berikut merupakan hasil dari estimasi parameter pada model ARIMA. Pada model ARIMA $(12,1,0)$ mempunyai nilai $p$-value 0,0088 dan nilai AIC sebesar 10,10501. Pada model ARIMA $(0,1,12)$ mempunyai $p$-value 0,0050 dan nilai AIC sebesar 10,10485. Pada model ARIMA $(12,1,12)$ mempunyai $p$-value sebesar 0,0026 dan 0,0005 dan nilai AIC sebesar 10,10326. Berdasarkan hasil output yang telah terbentuk, ketiga model ARIMA memiliki parameter yang signifikan, yaitu probabilitas $p$-value $<\alpha=0,05$. Selanjutnya pemilihan model ditunjukkan dengan kriteria pengukuran model yaitu dengan Akaike Info Criterion (AIC) yang bernilai paling kecil. Berdasarkan nilai AIC yang terkecil, maka didapatkan model ARIMA terbaik yaitu ARIMA $(12,1,12)$ atau AR 12 dan MA 12. 
Tabel 2 ACF DAN PACF

\begin{tabular}{|c|c|c|c|c|c|c|}
\hline Autocorrelation & Partial Correlation & & $\mathbf{A C}$ & PAC & Q-Stat & Prob \\
\hline & hit & 1 & 0.017 & 0.017 & 0.6263 & 0.429 \\
\hline & & 2 & -0.022 & -0.022 & 1.6506 & 0.438 \\
\hline & & 3 & -0.016 & -0.015 & 2.2176 & 0.528 \\
\hline & & 4 & -0.041 & -0.041 & 5.9437 & 0.203 \\
\hline & & 5 & -0.025 & -0.025 & 7.3703 & 0.195 \\
\hline & ] & 6 & -0.036 & -0.038 & 10.251 & 0.114 \\
\hline & 1 & 7 & -0.036 & -0.037 & 13.085 & 0.070 \\
\hline 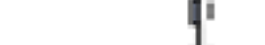 & 1 & 8 & 0.0003 & 0.000 & 13.108 & 0.108 \\
\hline 4 & 1 & 9 & 0.017 & 0.012 & 13.753 & 0.131 \\
\hline & 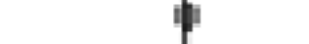 & 10 & -0.018 & -0.024 & 14.483 & 0.152 \\
\hline 10 & $d$ & 11 & -0.001 & -0.005 & 14.485 & 0.207 \\
\hline . & 1 & 12 & 0.049 & 0.046 & 19.873 & 0.070 \\
\hline & $t$ & 13 & 0.005 & 0.002 & $19 . .932$ & 0.097 \\
\hline & & 14 & -0.001 & -0.002 & 19.936 & 0.132 \\
\hline i & 1 & 15 & -0.042 & -0.040 & 23.782 & 0.069 \\
\hline 1 & 1 & & & & & \\
\hline
\end{tabular}

Sumber: Output Eviews10 (data diolah)

Tabel 3

UJI GARCH $(0,1)$

\begin{tabular}{cccc}
\hline Variable & Coefficient & Prob. & Hipotesis \\
\hline C & 0,538694 & 0,5174 & \\
D(INFLASI) & $-950,4689$ & 0,1762 & Ditolak \\
D(KURS) & 0,013261 & 0,3935 & Ditolak \\
D(BI_RATE) & 1194,571 & 0,8175 & Ditolak \\
D(PDB) & $-2818,284$ & 0,6052 & Ditolak \\
D(EMAS) & 0,279298 & 0,0024 & Diterima \\
D(WTI) & $-0,318250$ & 0,6828 & Ditolak \\
D(DJI) & 0,057206 & 0,0000 & Diterima \\
D(N225) & $-0,010579$ & 0,0026 & Diterima \\
AR(12) & $-0,057145$ & 0,8317 & \\
MA(12) & 0,112728 & 0,6733 & \\
\hline
\end{tabular}

Sumber: Output Eviews10 (data diolah)

Pemilihan model terbaik ARCH/GARCH dipilih berdasarkan nilai Akaike Information Criterion (AIC) dan Schwarz Bayesian Criterion (SBC) terkecil. Berikut merupakan hasil output dari model ARCH/GARCH yang terbentuk adalah pada model GARCH $(0,1)$ terbentuk nilai AIC yaitu 10,09799 dan SBC yaitu 10,11105. Pada model ARCH $(1,0)$ terbentuk nilai AIC yaitu 10,10510 dan SBC yaitu 10,11816. Pada model GARCH $(1,1)$ terbentuk nilai AIC yaitu: 10,13227 dan nilai SBC 10,14794.

Berdasarkan hasil output yang telah terbentuk, maka ditemukan model terbaik ARCH/GARCH berdasarkan nilai Akaike Info Criterion (AIC) dan Schwarz Bayesian Criterion (SBC) dengan nilai terkecil adalah pada model GARCH $(0,1)$.

Berdasarkan Tabel 3, 5 hipotesis dinyatakan ditolak dan 3 hipotesis dinyatakan diterima. Hal ini ditunjukkan dengan nilai probabilitas $<0,05$ dengan ditunjukkan data pada tabel 3 .

\section{Pengaruh Inflasi terhadap IHSG}

Berdasarkan hasil pengujian yang telah dilakukan, variabel inflasi tidak berpengaruh signifikan terhadap Indeks Harga Saham Gabungan periode 2014-2019. Hasil tersebut tidak selaras dengan 
Fadhil Ahmad. Analisis Pengaruh Makroekonomi, Komoditas Dunia, dan Indeks Dunia terhadap Indeks Harga Saham Gabungan (IHSG) pada Periode 2014-2019

hipotesis pertama sehingga hasil penelitian tersebut ditolak. Hasil ini selaras dengan penelitian (Tjandrasa \& Sutjiati, 2016) bahwasanya inflasi tidak memengaruhi IHSG. Hal ini dapat terjadi karena investor menganggap bahwa, fluktuasi inflasi tidak akan memengaruhi stock market karena market masih dapat berkenan apabila tingkat inflasi masih dibawah 10 persen. Untuk inflasi di Indonesia selama tahun 2014-2019 menurut Bank Indonesia (BI) hanya mencapai 4,4\% saja. Namun, apabila inflasi mencapai angka 10 persen atau bahkan lebih, IHSG di Indonesia akan sangat bergejolak. Apabila inflasi telah mencapai angka 10 persen, maka Bank Indonesia (BI) akan menaikkan BI rate yang menyebabkan beban hutang emiten akan bertambah. Selain itu, harga bahan baku juga akan naik sehingga menambah beban pada emiten, maka sangat mempengaruhi laporan keuangan pada emiten. Jika laporan keuangan emiten tersebut dalam keadaan tidak sehat maka investor enggan berinvestasi yang akan menyebabkan rendahnya daya minat investasi pada pasar modal akan berakibat turunnya harga saham emiten pada pasar modal.

Implikasi teoritis pada riset ini tidak sejalan dengan Signalling Theory, bahwa Inflasi berpengaruh terhadap Indeks Harga Saham Gabungan (IHSG). Harapan dari penelitian ini dapat menjadi sumbangsih untuk hasil penelitian yang menyatakan Inflasi tidak memengaruhi IHSG. Implikasi praktis dari riset ini yaitu inflasi tidak dianjurkan menjadi acuan bagi investor jika ingin berinvestasi di pasar modal karena inflasi yang terjadi di negara Indonesia masih dalam kategori sehat sehingga tidak mempengaruhi IHSG.

\section{Pengaruh Kurs terhadap IHSG}

Berdasarkan hasil pengujian yang telah dilakukan, variabel kurs tidak berpengaruh signifikan terhadap Indeks Harga Saham Gabungan periode 2014-2019. Hasil tersebut tidak selaras dengan hipotesis kedua sehingga hasil penelitian tersebut ditolak. Hasil ini berbeda dengan penelitian Handiani (2014); Mursalin et al (2017); Zoa et al (2014) dan Nasser et al (2017) yang menyatakan bahwa kurs berpengaruh positif terhadap Indeks Harga Saham Gabungan (IHSG). Hasil dari penelitian dapat terjadi karena investor menganggap fluktuasi dari mata uang Rupiah terhadap Dollar Amerika tidak akan memengaruhi pasar saham di indonesia karena kurs rupiah terhadap dollar amerika pada tahun 2014-2019 tidak terlalu berfluktuatif signifikan yaitu pada kisaran Rp12.000 sampai Rp 14.000 yang menyebabkan pergerakan nilai tukar tidak sensitif terhadap perubahan nilai IHSG (Zuhri, Hufron, \& Mustapita, 2019).

Implikasi teoritis pada riset ini tidak sejalan dengan Signalling Theory, bahwa Kurs berpengaruh terhadap Indeks Harga Saham Gabungan (IHSG). Harapan dari penelitian ini dapat menjadi sumbangsih untuk hasil penelitian yang menyatakan Kurs tidak memengaruhi IHSG. Implikasi praktis dari riset ini yaitu kurs tidak dianjurkan menjadi acuan bagi investor jika ingin berinvestasi di pasar modal karena Kurs Rupiah terhadap dollar tidak terlalu berfluktuatif signifikan.

\section{Pengaruh BI Rate terhadap IHSG}

Berdasarkan hasil pengujian yang telah dilakukan, variabel BI rate tidak berpengaruh signifikan terhadap Indeks Harga Saham Gabungan periode 2014-2019. Hasil tersebut tidak selaras dengan hipotesis ketiga sehingga hasil penelitian tersebut ditolak. Hasil ini sejalan dengan penelitian Pardede et al (2016) dan Nellawati \& Isbanah (2019) yang menyatakan bahwa BI rate tidak berpengaruh terhadap Indeks Harga Saham Gabungan (IHSG). Hasil dari penelitian ini dapat terjadi karena tipikal investor di negara Indonesia menyukai gaya trading saham dalam waktu yang pendek. Penanam modal berbondong-bondong melangsungkan aktivitas melego sahamnya pada saat stock price terjadi peningkatan atau bisa dikatakan profit taking yang menantikan imbalan capital gain yang sangat menggiurkan yang menyebabkan investor lebih senang melakukan investasi berbentuk instrumen saham daripada berbentuk intrumen deposito. Selain itu, Emiten dapat membuat kebijakan deviden yang cukup tinggi sehingga investor lebih menyukai berinvestasi yang berbentuk instrumen saham pada stock market daripada berinvestasi pada pasar uang karena keuntungannya kurang maksimal disbanding berinvestasi pada pasar modal. Tingkat suku bunga terus naik-turun, tetapi condong turun pada tahun riset yaitu pada tahun 2014 suku bunga mencapai 7,75\% dan menurun pada tahun 2019 yaitu hanya 5\% sehingga investor semakin tidak berminat pada pasar uang (Anati et al, 2019). 
Implikasi teoritis pada riset ini tidak sejalan dengan Signalling Theory, bahwa BI rate berpengaruh terhadap Indeks Harga Saham Gabungan (IHSG). Harapan dari penelitian ini dapat menjadi sumbangsih untuk hasil penelitian yang menyatakan BI rate tidak memengaruhi IHSG. Implikasi praktis dari riset ini yaitu BI rate tidak dianjurkan menjadi acuan bagi investor jika ingin berinvestasi di pasar modal karena menurut investor BI rate tidak memberikan hasil yang signifikan.

\section{Pengaruh PDB terhadap IHSG}

Berdasarkan hasil pengujian yang telah dilakukan, variabel PDB tidak berpengaruh signifikan terhadap Indeks Harga Saham Gabungan periode 2014-2019. Hasil tersebut tidak selaras dengan hipotesis keempat sehingga hasil penelitian tersebut ditolak. Hasil ini sejalan dengan penelitian Akbar (2016); Rustyaningsih (2018) dan Dwi Puspita \& Seno Aji (2018) yang menyatakan bahwasanya PDB tidak bepengaruh signifikan terhadap Indeks Harga Saham Gabungan (IHSG). Hasil penelitian ini terjadi karena kenaikan PDB mencerminkan kemakmuran masyarakat di negara tersebut juga meningkat. Naiknya kemakmuran masyarakat dapat memotivasi masyarakat supaya banyak menggunakan barang dan jasa dan kemudian akan meningkatnya investasi pada sektor riil. Namun meningkatnya nilai PDB, belum dapat diseimbangkan dengan naiknya investasi oleh sektor lainnya di pasar modal. Ada beberapa faktor lainnya yang harus dilihat adalah di antaranya perluasan kemakmuran masyarakat. Naiknya PDB belum bisa melakukan pemasukan setiap orang bertambah sehingga jumlah investasi tidak terpengaruh oleh peningkatan PDB (Kewal, 2012).

Implikasi teoritis pada riset ini tidak sejalan dengan Signalling Theory, bahwa PDB berpengaruh terhadap Indeks Harga Saham Gabungan (IHSG). Harapan dari penelitian ini dapat menjadi sumbangsih untuk hasil penelitian yang menyatakan PDB tidak memengaruhi IHSG. Implikasi praktis dari riset ini yaitu PDB tidak dianjurkan menjadi acuan bagi investor jika ingin berinvestasi di pasar modal karena dengan naiknya PDB di Indonesia belum dapat diseimbangkan dengan naiknya investasi oleh sektor lainnya di pasar modal.

\section{Pengaruh World Gold Price terhadap IHSG}

Berdasarkan hasil pengujian yang telah dilakukan, variabel World Gold Price berpengaruh positif dan signifikan terhadap Indeks Harga Saham Gabungan periode 2014-2019. Hasil tersebut selaras dengan hipotesis kelina sehingga hasil penelitian tersebut ditolak. Hasil riset ini sejalan dengan riset terdahulu yang diteliti oleh Rustyaningsih (2018) menyatakan bahwasanya World Gold Price memiliki dampak positif dan signifikan terhadap Indeks Harga Saham Gabungan (IHSG).

Dengan naiknya harga emas dunia, investor mendapatkan alternatif untuk menciptakan portofolio yang lebih bagus, dikarenakan gold adalah instrumen yang mempunyai risiko yang minim dan efisien untuk ditransaksikan. Penjelasan tentang portofolio bahwasanya untuk mengecilkan risk, maka butuh diadakan diversifikasi, yaitu membuat portofolio atau mengalokasikan uang tidak hanya pada sedikit aset saja, tetapi pada bermacam-macam aset dengan ketentuan tertentu. Jika world gold price naik, maka investor bisa mengatur strategi besaran aset bebas risikonya berbentuk emas untuk saving nilai portofolionya tanpa kecemasan dalam berinvestasi pada pasar modal (Tjandrasa \& Sutjiati, 2016)

Implikasi teoritis pada riset ini sejalan dengan Contagion Theory, bahwa World Gold Price berpengaruh terhadap Indeks Harga Saham Gabungan (IHSG). Harapan dari penelitian ini dapat menjadi sumbangsih untuk hasil penelitian yang menyatakan World Gold Price memengaruhi IHSG. Implikasi praktis dari riset ini yaitu World Gold Price dianjurkan menjadi acuan bagi investor jika ingin berinvestasi di pasar modal karena jika World Gold Price harganya naik, investor mendapatkan alternatif untuk menciptakan portofolio yang lebih bagus.

\section{Pengaruh World Oil Price terhadap IHSG}

Berdasarkan hasil pengujian yang telah dilakukan, variabel World Oil Price tidak berpengaruh dan signifikan terhadap Indeks Harga Saham Gabungan periode 2014-2019. Hasil riset ini sejalan dengan riset terdahulu yang diteliti oleh Tjandrasa \& Sutjiati (2016); Nordin et al, (2014); Rustyaningsih (2018); Maulinda (2018); Hersugondo et al, (2015) dan Nellawati \& Isbanah (2019) yang mengatakan 
Fadhil Ahmad. Analisis Pengaruh Makroekonomi, Komoditas Dunia, dan Indeks Dunia terhadap Indeks Harga Saham Gabungan (IHSG) pada Periode 2014-2019

bahwasanya World Oil Price tidak mempunyai dampak terhadap Indeks Harga Saham Gabungan (IHSG). Hasil riset ini dapat terjadi karena setiap naiknya world oil price yang dipengaruhi spekulasi lembaga lindung nilai dan dampak situasi geopolitik pada negata Timur Tengah. Adanya penanggulangan dari pemerintah Indonesia yang diterbitkannya peraturan subsidi pada beberapa bahan bakar yang dimaksudkan untuk menjauhkan efek penularan dari kenaikan harga minyak mentah, hal tersebut dapat menyebabkan kondisi ekonomi tetap stabil. Kebijakan yang duterbitkan oleh pemerintah memberikan dampak yang baik, khusus nya di stock market. Pasar modal tidak mendapatkan pengaruh apapun ketika crude oil mengalami peningkatan, hal ini dikarenakan minyak mentah merupakan faktor utama dalam proses produksi. Kenaikan oil price mengakibatkan naiknya cost production dan penurunan produksi. Hal tersebut dapat diatasi dengan pemberlakuan subsidi dari yang diberikan oleh pemerintah. Hasil dari pemberlakuan kebijakan tersebut ialah kurva penawaran makro tidak mengalami penggeseran dan hanya dapat menstimulasi sehingga harga minyak dunia tidak memengaruhi investor dalam kegiatan yang berlangsung di stock market (Nellawati \& Isbanah, 2019). Hal tersebut melatarbelakangi peningkatan harga crude oil tidak memberikan pengaruh yang signifikan terhadap Indeks Harga Saham Gabungan (IHSG).

Implikasi teoritis pada riset ini tidak sejalan dengan Contagion Theory, bahwasanya World Oil Price berpengaruh terhadap Indeks Harga Saham Gabungan (IHSG). Harapan dari penelitian ini dapat menjadi sumbangsih untuk hasil penelitian yang menyatakan World Oil Price tidak memengaruhi IHSG. Implikasi praktis dari riset ini yaitu World Oil Price tidak dianjurkan menjadi acuan bagi investor jika ingin berinvestasi di pasar modal karena dengan adanya kebijakan subsidi dari pemerintah sehingga tidak memengaruhi dalam kegiatan yang berlangsung di stock market.

\section{Pengaruh Dow Jones Indutrial Average (DJIA) terhadap IHSG}

Berdasarkan hasil pengujian yang telah dilakukan, variabel DJIA berpengaruh positif dan signifikan terhadap Indeks Harga Saham Gabungan periode 2014-2019. Hasil riset ini sejalan dengan riset terdahulu yang diteliti oleh Marjohan (2015); Kowanda et al, (2014); Maulinda (2018) Andiyasa et al, (2014) dan Sari \& Purwohandoko, (2019) mengatakan bahwasanya Dow Jones Index Average mempunyai dampak yang positif dan signifikan terhadap Indeks Harga Saham Gabungan (IHSG).

Hasil penelitian ini terjadi karena Dow Jones Index Average (DJIA) ialah indeks yang paling besar dan tertua di Amerika Serikat, dimana negara tersebut telah menjalin kegiatan ekspor terbesar dari negara Indonesia. Hal tersebut menyebabkan negara Amerika jika keadaan perekonomian yang bagus ataupun stabil dapat memberi pengaruh pada negara Indonesia. Masuknya investor asing dapat menanamkan modalnya dalam pasar modal di Indonesia. Berdasarkan data yang diakses oleh bps.go.id, ekspor di Indonesia menuju Amerika ialah ekspor terbesar kedua yang mencapai US\$13 miliar yang terjadi pada tahun 2019 sehingga para investor tertarik untuk menanamkan modal dalam pasar modal di Indonesia (Anggraini \& Nurhadi, 2019).

Implikasi teoritis pada riset ini sejalan dengan Contagion Theory, bahwasanya DJIA berpengaruh terhadap Indeks Harga Saham Gabungan (IHSG). Harapan dari penelitian ini dapat menjadi sumbangsih untuk hasil penelitian yang menyatakan DJIA memengaruhi IHSG. Implikasi praktis dari riset ini yaitu DJIA dianjurkan menjadi acuan bagi investor jika ingin berinvestasi di pasar modal, karena Indonesia merupakan negara eksportir terbesar kedua menuju Amerika yang mencapai US\$13 miliar pada tahun 2019.

\section{Pengaruh Nikkei225 terhadap IHSG}

Berdasarkan hasil pengujian yang telah dilakukan, variabel Nikkei225 berpengaruh negatif dan signifikan terhadap Indeks Harga Saham Gabungan periode 2014-2019. Hasil riset ini sejalan dengan riset terdahulu yang diteliti oleh Kowanda et al, (2014) dan Andiyasa et al, (2014) mengatakan bahwasanya Nikkei225 mempunyai dampak negatif dan signifikan terhadap Indeks Harga Saham Gabungan (IHSG).

Hasil penelitian ini terjadi karena menurut website id.tradingeconomics.com, PDB pada negara Jepang pada tahun 2014-2019 hanya mencapai 0,85\% yang membuat investor pada negara Jepang 
kurang diminati sehingga investor mencari negara yang berkembang dalam pertumbuhan ekonominya. Indonesia merupakan tujuan yang tepat menurut investor, karena PDB Indonesia pada tahun 2014-2019 mencapai 5\%. Data tersebut didukung juga negara Jepang merupakan negara kedua terbesar tujuan ekspor dari Indonesia sehingga investor sangat tertarik terhadap negara Indonesia dan investor telah banyak meninggalkan negara Jepang menuju negara Indonesia dengan tujuan berinvestasi.

Implikasi teoritis pada riset ini sejalan dengan Contagion Theory, bahwasanya Nikkei225 berpengaruh terhadap Indeks Harga Saham Gabungan (IHSG). Harapan dari penelitian ini dapat menjadi sumbangsih untuk hasil penelitian yang menyatakan Nikkei225 memengaruhi IHSG. Implikasi praktis dari riset ini yaitu Nikkei225 dianjurkan menjadi acuan bagi investor jika ingin berinvestasi di pasar modal, karena PDB jepang pada tahun 2014-2019 hanya 0,85\% yang membuat investor pada negara Jepang kurang dimintai, sedangkan pada negara Indonesia PDB nya mencapai angka 5\% sehingga investor tertarik untuk berinvestasi di Indonesia.

\section{KESIMPULAN}

Penelitian ini dilakukan dengan tujuan untuk menganalisis Makroekonomi, Komoditas Dunia dan Indeks Dunia terhadap Indeks Harga Saham Gabungan (IHSG). Teknik analisis yang digunakan adalah Generalized Autoregressive Conditional Heterokedasticity (GARCH), maka hasil yang didapatkan dari penelitian ini adalah: (1) Inflasi tidak berdampak signifikan terhadap IHSG. (2) Nilai kurs tidak berpengaruh terhadap IHSG. (3) BI Rate tidak berpengaruh terhadap IHSG. (4) PDB tidak berpengaruh terhadap IHSG. (5) World Gold Price berpengaruh positif dan signifikan terhadap IHSG. (6) World Oil Price tidak berpengaruh terhadap IHSG. (7) Dow Jones Industrial Average berpengaruh positif terhadap IHSG. (8) Nikkei225 berpengaruh negatif terhadap IHSG.

Terdapat beberapa keterbatasan yang ditemukan pada penelitian ini, di antaranya data pada variabel inflasi, BI rate dan PDB tidak menggunakan time series harian sehingga keakuratannya masih dikatakan kurang. Disarankan untuk menggunakan variabel yang terdapat time series harian. untuk peneliti selanjutnya disarankan untuk menambahkan teknik analisis untuk memprediksi IHSG dalam beberapa tahun kedepan agar para investor mempunyai pandangan apakah IHSG masih layak untuk dijadikan sarana investasi.

\section{DAFTAR PUSTAKA}

Akbar, N. W. S. A M. (2016). Analisis Pengaruh Inflasi, Suku Bunga, Nilai Tukar (Kurs) Dan Pertumbuhan Produk Domestik Bruto (Pdb) Terhadap Indeks Harga Saham Gabungan (Ihsg) Studi Kasus Pada Perusahaan Properti Yang Terdaftar Di Bursa Efek Indonesia. Jurnal Manajemen Dan Akuntansi, 17(1), 43-52.

Alim, S. (2014). Analisis Pengaruh Inflasi Dan Bi Rate Terhadap Return on Assets (Roa) Bank Syariah Di Indonesia. Jurnal Ekonomi MODERNISASI, 10(3), 201. https://doi.org/10.21067/jem.v10i3.785

Anati, F. A., Mardani, R. M., \& Wahono, B. (2019). Pengaruh Kurs, Inflasi, Suku Bunga Sbi dan Indeks Bursa Internasioal Terhadap Indeks Harga Saham Gabungan. E-Jurnal Riset Manajemen, 1, 28-45.

Andiyasa, I. G. A., Purbawangsa, I. B. A., \& Henny, R. (2014). Indikator Ekonomi Global Terhadap Kondisi Pasar Modal Indonesia. E-Jurnal Manajemen, 1, 182-199.

Anggraini, F. N., \& Nurhadi. (2019). Indeks Dow Jones Industrial Average (DJIA), Indeks Shanghai Stock Exchange (SSE), Kurs USD/IDR Dan BI Rate Berpengaruh Terhadap Indeks Harga Saham Gabungan (IHSG) Di Bursa Efek Indonesia (BEI) Periode 2015-2018. Jurnal Bisnis 
Fadhil Ahmad. Analisis Pengaruh Makroekonomi, Komoditas Dunia, dan Indeks Dunia terhadap Indeks Harga Saham Gabungan (IHSG) pada Periode 2014-2019

Indonesia, 10(1), 57-69.

Asean Exchange. (2019). Retrieved November 19, 2019, from https://www.aseanexchanges.org/\#/

Astiyah Siti, \& Suseno. (2009). In fl a s i. Jakarta: bi.go.id.

BKPM. (2019). Badan Koordinasi Penanaman Modal. Retrieved November 21, 2019, from https://www.bkpm.go.id/id/publikasi/detail/berita/nilai-investasi-kuartal-i-tembus-rp1951triliun/

Diskartes. (2017). Risiko Investasi Saham Yang Harus Anda Pahami. Retrieved November 16, 2019, from https://diskartes.com/2017/07/risiko-investasi-saham/

Dwi Puspita, M., \& Seno Aji, T. (2018). Analisis Pengaruh Inflasi, Suku Bunga SBI, Nilai Tukar, Produk Domestik Bruto (PDB) dan Indeks Dow Jones Industrial Average (DJIA) Terhadap Indeks Kompas 100 Periode Januari 2012-Desember 2017. Jurnal Ilmu Manajemen (JIM), 6(3), 333-341.

Dwiati, A. R., \& Ambarwati, Y. B. (2016). Pengaruh Harga Emas Terhadap Indeks Harga Saham Gabungan Indonesia dengan Nilai Kurs Sebagai Variabel Moderating. E-Jurnal Manajemen \& Bisnis , 1-9.

Fahmi, I. (2012). Analisis Kinerja Perusahaan (1st ed.). Bandung: alfabeta.

Ghiffari, M. F., Kindangen, P., \& Tumewu, F. (2017). The Causality Relationship Of Dow Jones Industrial Average (Djia) And Nikkei 225 Towards Jakarta Composite Index (Jci) Period 2011 - 2016. Jurnal EMBA, 5(2), 445-454.

Gunawan, J. L. (2014). Pengaruh Inflasi, Suku Bunga Sbi, Pdb Dan Nilai Tukar Terhadap Indeks Harga Saham Gabungan (Ihsg) Di Bursa Efek Indonesia Tahun 2000-2014. Parsimonia, 1-16.

Handiani, S. (2014). Pengaruh Harga Emas Dunia, Harga Minyak Dunia dan Nilai Tukar Dolar Amerika/Rupiah Terhadap Indeks Harga Saham Gabungan Pada Periode 2008-2013. E-Journal Graduate Unpar, 1(1), 85-93. Retrieved from http://journal.unpar.ac.id/index.php/unpargraduate/article/view/552

Hersugondo, Robiyanto, Wahyudi, S., \& Muharam, H. (2015). The world oil price movements and stock returns in several southeast Asia's capital markets. International Journal of Applied Business and Economic Research, 13(2), 527-534.

Iman Zabidi, I., \& Asandimitra Haryono, N. (2018). Pengaruh Inflasi, Kurs, Suku Bunga Sbi, Dow Jones, Dan Nikkei 225 Terhadap Indeks Harga Saham Gabungan Pada Bursa Efek Indonesia Periode 2012-2016. Jurnal Ilmu Manajemen (JIM), 6(4), 468-476.

Investing.com. 2019. Grafik Indeks Sektoral. (www.investing.com, Diakses pada 29 September 2019).

Juliana, A., Hamidatun, \& Muslima, R. (2019). Modern Forecasting (1st ed.). Sleman: www.deepublish.com

Katircioglu, S. T., Sertoglu, K., Candemir, M., \& Mercan, M. (2015). Oil price movements and macroeconomic performance: Evidence from twenty-six OECD countries. Renewable and Sustainable Energy Reviews, 44, 257-270. https://doi.org/10.1016/j.rser.2014.12.016

Kewal, S. S. (2012). Pengaruh Inflasi, Suku Bunga, Kurs, Dan Pertumbuhan Pdb Terhadap Indeks 
Harga Saham Gabungan. Jurnal Economia, 8(1), 53-64. https://doi.org/10.21831/economia.v8i1.801

Kowanda, D., Binastuti, S., \& Pasaribu, R. B. F. (2014). Pengaruh Bursa Saham Global, Asean , Dan Harga Komoditas Terhadap Indeks Harga Saham Gabungan. Jurnal Akuntansi \& Manajemen (JAM). 25(2), 79-88.

Malhotra, N. K. (2010). Riset Pemasaran (Marketing Research) (4th ed.). New Jersey: PT. Indeks.

Mangala, D., \& Rani, A. (2015). Revisiting the Dynamic Relationship between Macroeconomic Fundamentals and Stock Prices: An Evidence from Indian Stock Market. International Journal of Financial Management, 5(3), 53-63. https://doi.org/10.21863/ijfm/2015.5.3.017

Marjohan, M. (2015). Effect of Stock Price Index in Global Stock againstComposite Stock Price Index (CSPI)Study on the Indonesia Stock Exchange. IOSR Journal of Economics and Finance Ver III, 6(2), 2321-5933. https://doi.org/10.9790/5933-06231523.

Martin (2014). Indeks Dow Jones 30 Yang Harus Anda Tahu. Retrieved November 21, 2019, from https://www.seputarforex.com/artikel/indeks-dow-jones-30-yang-harus-anda-tahu-186441-34.

Maulinda, T. S. (2018). Pengaruh Harga Minyak Dunia, Nilai Tukar, Inflasi, Suku Bunga SBI, Indeks Dow Jones, dan Indeks Nikkei 225 terhadap Indeks Sektor Pertambangan yang Terdaftar Di Bursa Efek Indonesia (BEI) Periode 2011-2017. Jurnal Ilmu Manajemen (JIM), 6(3), 314-322.

Mursalin, A., Oktaviani, D., Aisyah, \& Niswan, E. (2017). The Influence Of Dollar Exchange Rate, The Dow Jones Index And The Interest Rate Of Bank Indonesia Certificates (SBI) On The Composite Stock Price Index (During The Period Of January 2015 To December 2015). International Journal on Recent Trends in Business and Tourism, 1(04), 69-79.

Nasser, F. A. M., Rosid, C. M. A. C., \& Baharuddin, N. S. (2017). Relation between Macroeconomic Variables and ASEAN Stock Index. Terengganu International Finance and Economics Journal 5(1), 7-13.

Nellawati, S. O., \& Isbanah, Y. (2019). Analisis pengaruh faktor internal dan faktor eksternal terhadap pergerakan indeks harga saham gabungan (ihsg) di bursa efek indonesia periode 2012 - 2016. Jurnal Ilmu Manajemen (JIM). 7(1), 113-123.

Nordin, N., Nordin, S., \& Ismail, R. (2014). The impact of commodity prices, interest rate and exchange rate on stock market performance: an empirical analysis from Malaysia. Malaysian Management Journal, 18, 39-52.

Otorima, M., \& Kesuma, A. (2016). Pengaruh Nilai Tukar, Suku Bunga, Inflasi, Jumlah Uang Beredar Dan Pdb Terhadap Indeks Harga Saham Gabungan (Ihsg) Periode 2005-2015. Jurnal Terapan Manajemen Dan Bisnis, 53(9), 12-24. https://doi.org/10.1017/CBO9781107415324.004

Pamungkas, B. C., \& Darwan, A. (2018). Pengaruh Nilai Tukar USD Dan Bursa Asean Terhadap Indeks Harga Saham Gabungan (IHSG) ( Studi pada Bursa Efek Indonesia Periode 2014 - 2016 ). Jurnal Administrasi Bisnis, 60(1), 73-81.

Pamungkas, B. S., \& Prasetiono. (2018). Analisis Pengaruh Harga Minyak Dunia , Kurs Pasar Saham Di Indonesia. Diponegoro Journal of Management. 7(2), 1-14.

Pardede, N., Hidayat, R. R., \& Sulasmiyati, S. (2016). Pengaruh Harga Minyak Mentah Dunia, Inflasi, Suku Bunga (Central Bank Rate), Dan Nilai Tukar (Kurs) Terhadap Indeks Harga Saham Sektor Pertambangan Di Asean. Jurnal Administrasi Bisnis, 39(1), 130-138. 
Fadhil Ahmad. Analisis Pengaruh Makroekonomi, Komoditas Dunia, dan Indeks Dunia terhadap Indeks Harga Saham Gabungan (IHSG) pada Periode 2014-2019

Pribadi, A. K. (2016). Pengaruh Harga Minyak Mentah Dunia, Dow Jones Industrial Average, dan Inflasi Terhadap Harga Saham Perusahaan Di BEI. IOSR Journal of Economics and Finance, 3(1), 1-217. https://doi.org/https://doi.org/10.3929/ethz-b-000238666

Puspitasari, A., Siregar, H., \& Andati, T. (2015). Analisis Integrasi Bursa Saham ASEAN 5 (Analysis of Stock Exchange Integration of ASEAN 5). Jurnal Ekonomi Dan Kebijakan Pembangunan, 4(2), 187-204.

Riga, M. H., Indriana, V., \& Rahmanto, F. (2016). The Effects of Crude Oil Price Changes on the Indonesian Stock Market: A Sector Investigation. Indonesian Capital Market Review, 8(1), 12 22. https://doi.org/10.21002/icmr.v8i1.5442

Robiyanto, \& Fajar Hartanto, A. (2018). Contagion Effect Dan Integrasi Pasar Modal Di Kawasan Asia, Eropa Dan Amerika. Jurnal Organisasi Dan Manajemen, 14(1), 1-9. https://doi.org/10.33830/jom.v14i1.138.2018

Rustyaningsih, D. (2018). Pengaruh Pdb, Inflasi, Nilai Tukar, Harga Minyak Dunia, Harga Emas Dunia Dan Indeks Nikkei 225 Terhadap Indeks Sektor Pertambangan Periode 2011-2016. Jurnal Ilmu Manajemen (JIM), 6(4), 609-619.

Sari, N. S., \& Purwohandoko. (2019). Dampak Pengaruh Bursa Saham Global, Harga Emas Dunia dan Variabel Makroekonomi Terhadap Indeks Harga Saham Gabungan Periode 2009-2018. Jurnal Ilmu Manajemen (JIM), 7(3), 772-783.

Sugiyono. (2017). Metode Penelitian Kuantitatif, Kualitatif, dan R\&D. Bandung: ALFABETA.

Syaifuddin, D., Sarita, B., \& Mahrani, S. W. (2015). Manajemen Keuangan Internasional. Yogyakarta: Kurnia Global Diagnostika

Syarif, M. M., \& Asandimitra, N. (2015). Pengaruh Indikator Makro Ekonomi Dan Faktor Global Terhadap Indeks Harga Saham Gabungan (IHSG). Competence: Journal of Management Studies, 9(2), 142-156.

Tandelilin. (2010). Portofolio dan Investasi Teori dan Aplikasi (1st ed.). Yogyakarta: BPFEYogyakarta.

Tjandrasa, B. B., \& Sutjiati, R. (2016). Effect of World Gold Price, Crude Oil Price and Interest Rate to Jakarta Composite Index. International Journal of Education and Research, 4(7), 215-222. Retrieved from www.ijern.com

UFX (2016). Perdagangan Indeks Nikkei225. Retrieved November 23, 2019, from https://www.ufx.com/id-id/aset/indeks/nikkei/

Zoa, C. H., Chet, F. W., Sheng, H. Y., Lin, W. H., \& Shen, Y. J. (2014). The Impact of Macroeconomic Variables on the Stock Market Performance in Japan. E-Journals. UTAR, 1139.

Zuhri, S., Hufron, M., \& Mustapita, A. F. (2019). Pengaruh Inflasi, kurs, dan BI Rate terhadap Indeks Harga Saham Gabungan Bursa Efek Indonesia (BEI) Periode 2014 - 2018. E-Jurnal Riset Manajemen, 1, 41-55. 